\title{
REPRODUCTIVE BEHAVIOR OF CYCLORAMPHUS DUBIUS MIRANDA-RIBEIRO (AMPHIBIA, ANURA, LEPTODACTYLIDAE)
}

\author{
Ariovaldo A. Giaretta ${ }^{1}$ \\ Adão J. Cardoso"
}

\begin{abstract}
Cycloremphus duhius Miranda-Ribeiro, 1920) is a frog species from the coastal Atlantic Forest in Southeastern Brazil It uses waterfallsof forested rivulets as breeding sites. The eggs are placed outside of water. between rock erevices or roots constantly welled by water dripping. Clutches have ahout 60) eggs, and the tadpoles grow attached to rocks. out of water. Males of this species exhihit parental care, hiting and/or pushing away strange objects approaching the egg masses. Two types of ealls were identified in the spectrograms. The "advertisement calls" consist of juxtaposed pulses lasting $200 \mathrm{~ms}$; the "aggressive calls". also have the shont pulses structure, and last around $300 \mathrm{~ms}$. The aggressive calls are emilted during territorial invasion.

KEY WoRDS. Amphibia, Anura, Atlantic Forest, breeding site territoriality. parental care
\end{abstract}

Species of the genus Cycloramphus Tschudi, 1838 are restricted to the coastal Atlantic Forest, Brazil (HEYER 1983). MIRANDA-RIBEIRo) (1926) referred to direct development in two uncertainly determined species of Cyclormmphus. LUTz (1929) described the reproductive behavior of Cycloramplius brasiliensis Steindachner, 1864. Besides these ancient and brief studies many details of the reproductive traits of the species of the genus Cycloramphus remain unknown. Herein are described some reproductive characteristics, as paternal care and territorial hehavior, of Cycloramphus duhius (Mir.-Rib.. 1920).

\section{AREA DESCRIPTION AND METHODS}

A population of Cyclorumphus duhius was studied on a small tributary of the Rio Quilombo, Santos municipality, São Paulo State, Brazil $\left(23^{\circ} 47^{\circ} \mathrm{S}\right.$ $\left.46^{\circ} 18^{\circ} \mathrm{W}\right)$, at different times from 1988 to 1991. The local is typical Atlantic Rain Forest ( $80 \mathrm{~m}$ elevation, $3,400 \mathrm{~mm}$ rain/year). The streams where the species lives have a sandy or granite rock bed. They undergo large and sudden alterations in volume by local rain events, but, under normal conditions, are about $20 \mathrm{~cm}$ in depth and $1.4 \mathrm{~m}$ wide. In the field, it was performed direct ohservation on calling and offspring guarding males. In order to study males aggressive hehavior, some egg masses was touched with sticks and introduced foreign living individuals of

1) Departamento de Zoologia. Universidade Estadual de Campinas. Caixa Postal 6109. 13(1)8.3-470) Campinas. São Paulo. Brasil. 
the same species was introduced in previously occupied sites. Males also were tested in response to call playback. One clutch was collected and kept in a terrarium under laboratory observation. Vocalizations were recorded with a UHER 4000 IC set at $19 \mathrm{~cm} / \mathrm{s}$, and spectrograms were made using a Sound Spectrograph series MD-700 from Voice Identification Inc.. A voucher specimen is housed at the Museu de História Natural, Universidade Estadual de Campinas (ZUEC 6690).

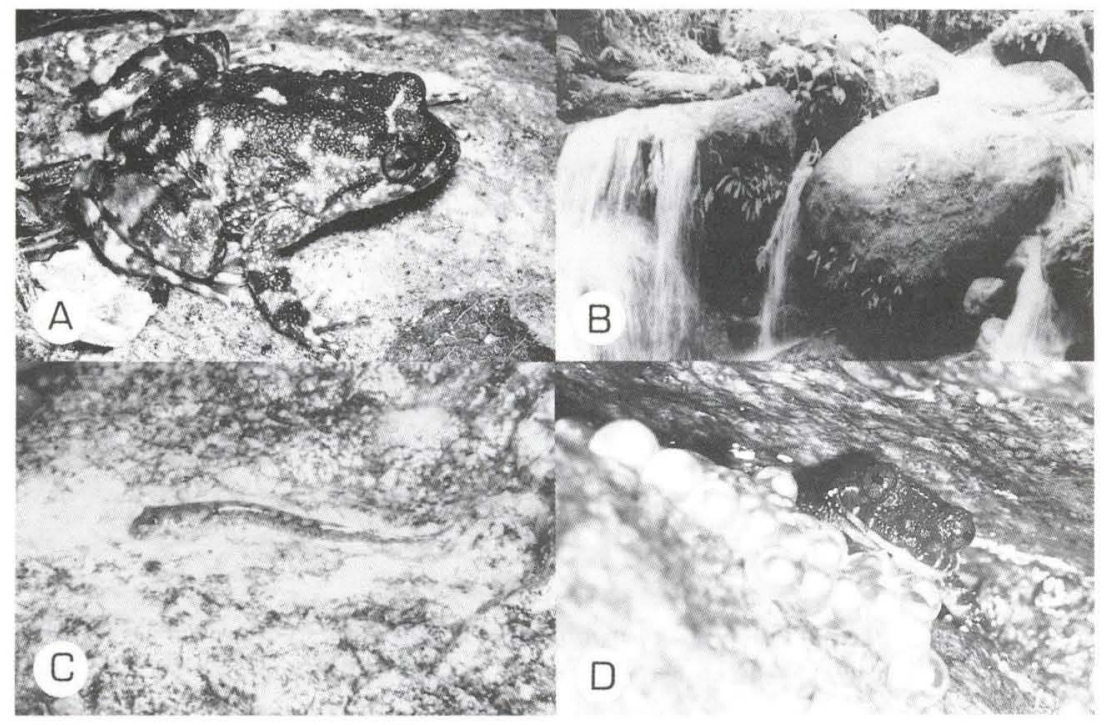

Fig. 1. Environment and life stages of Cycloramphus dubius; (A) adult male (ca. $48 \mathrm{~mm}$ ); (B) waterfall in the study site used by the species for reproductive activities; (C) tadpole on a wet rock surface (ca. $29 \mathrm{~mm}$ ); (D) clutch guarded by an adult male (photo by $E$. Ramirez).

\section{RESULTS}

Male Cycloramphus dubius (Fig. 1A) are about $46 \mathrm{~mm}$ long and flattened dorso-ventrally. Small noisy waterfalls (Fig. 1B) are used by the species as breeding sites. Reproductive activity of the species occurs throughout the year, as indicated by the presence of calling males, clutches and tadpoles. Clutches (Fig. 1D) were found in narrow crevices of rocks and between roots. All 16 clutches found were outside of water, in places with constant water dripping or waterfall spray, but never in places subject to washing by water flow. Clutches contain 30 to 80 eggs $(\bar{X}=60.3 ; \mathrm{SD}=22.7 ; \mathrm{N}=4)$. The eggs are deposited in a single layer, weakly adherent to the substrate and to one another. The yolk portion of the eggs is cream color and measures about $3 \mathrm{~mm}$ in diameter, each egg having a transparent gelatinous-like capsule. The occurrence of gelatinous spheres without yolk (nurse eggs) and unfertilized eggs in the clutch is common. Embryos develop within the egg capsules until stage 25 (GOSNER 1960), when they reach about $19 \mathrm{~mm}$. The 
tadpoles of $C$. dubius (Fig. IC) were found out of water, feeding above wet rocks.

From the 16 clutches encountered, 15 had a male sitting by the side (Fig. ID). The males remained with their eggs both day and night. In the field two tests was performed with males that were near their clutches: 1) a cloth tied to the end of a stick was hung over a clutch. The male, distant $10 \mathrm{~cm}$ away, jumped on to the cloth, bit and pushed it away. About half the clutch was collected and the male was expelled. On the following day a male, probably the same one, was guarding the remaining eggs and, also at this time, responded aggressively, hiting the cloth on the stick. 2) It was introduced, separately, males near a guarded clutch. One of the introduced males jumped in the direction of the clutch and the guardian reacted by emitting vocalizations (Fig. 2E) and engaged in a fight. When it was induced a foreign male to approach another resident male without eggs, the resident reacted hy emitting calls (Fig. 2E), hiting and pushing the intruder away. Adult males vocalize at night from rock crevices of the waterfalls, whereas diurnal vocalizations are rare. The advertisement calls (Fig. 2A-D) of $C$. dubius is emitted with an average rate of one call every 25 seconds. Each note consisted of juxtaposed pulses lasting about $200 \mathrm{~ms}$. During call emission, there is a discrete modulation of the highest frequencies. The first pulse has a frequency range between 1.2 and $3.1 \mathrm{kHz}$; the last pulse has a lower frequency range hetween 1.5 and $2.3 \mathrm{kHz}$. Although the call resembles a pure sound structure, it consists of pulses separated by very short time intervals. The intervals between the pulses are irregular (1.2 to $3.8 \mathrm{~ms}$ ), with marked variahility in the lower note frequencies (Fig. 2A,C). The call emitted by a guardian when disturbed by the introduction of another male into its rock crevice was characterized hy a multipulsed note with longer duration and wider bandwidth frequency (Fig. 2E), which was interpreted as an aggressive call. These vocalizations consist of calls given at a faster rate (around 1.2 seconds between the calls) than the advertisement call; the pattern of emission appears to be related to the degree of aggressiveness of the emitter. The duration of the aggressive call is around $300 \mathrm{~ms}$ and the pulses are emitted in ascendant frequencies between 1.0 and $2.0 \mathrm{kHz}$. In response to playback of the aggressive calls a guardian emitted longer notes, in a faster rhythm: around $400 \mathrm{~ms}$ duration with ahout $700 \mathrm{~ms}$ between notes (Fig. 2F).

\section{DISCUSSION}

Some reproductive characteristics described for Cyclermmphus brasilic nsis by LUTz (1929) are similar to those of Cycloramphus dubius, including egs laying sites and clutch size. LUTz (1972) briefly wrote about the genus Cycloramphus: "the large forms lay the spawn on the ledges of rocks and the male parent graads it". WELLS (1981) considered parental care hehavior in frogs as uncommon and. in general, related to the terrestrialism of pre-metamorphic developmental phases. mainly in tropical regions. Terrestrial salamanders with parental care, generally. have large eggs, low fecundity and an enhanced embryonic period. Among them, behavior such as parental care could reduce the risk of embryo loss during the long embryonic period (NussBaun \& SCHULTz 1989). These statements could also be 

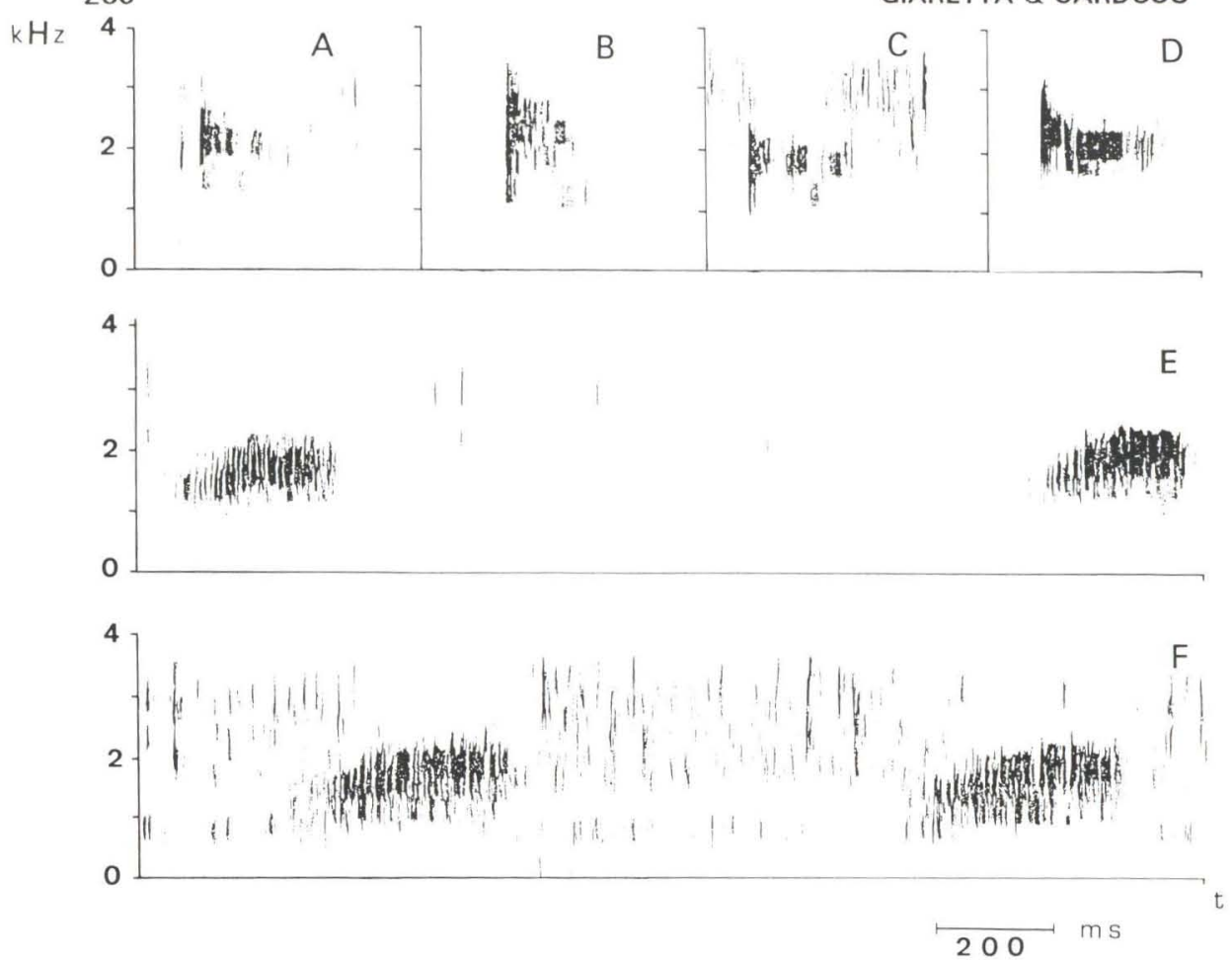

Fig. 2. Spectrograms of the vocalizations of Cycloramphus dubius. (A-D) Different physical structures of advertisement call found in the population; $(E)$ aggressive calls emitted by a resident male in presence of another male; $(F)$ aggressive calls emitted in response to playback of aggressive calls. The irregular marks of sounds up to $3.7 \mathrm{kHz}$ represent waterfall noise. Air temperature $19^{\circ} \mathrm{C}$, water $17^{\circ} \mathrm{C}$.

true for $C$. dubius as evidenced by the similarities in egg/clutch size and developmental characteristics. In C. dubius, as well as many species with paternal care, the males also exhibit territorial behavior (Williams 1975). A general characteristic of frog territorial behavior is the guarantee of access to limited resources (WELLS 1977). Suitable laying sites appear to be a limited resource for C. dubius because, in spite of the numerous crevices between rocks, the majority of them became inundated during rains or are outside of splash zones. The advertisement calls of $C$. dubius studied were similar to those described by HEYER \& MELlo (1979), later considered by HeYER (1983) as Cycloramphus boraceiencis. The advertisement call is quite variable in some parameters. The aggressive calls are also variable and are influenced by the behavioral context, such as the presence of intruding males. ROSE \& LEMON (1974) recognized space maintenance by the existence of distinctive types of vocalization exclusively emitted in eminent physical combats, which were suppressed after elimination of the neighbor calling male, as was found in $C$. dubius. Aggressive response to conspecific aggressive calls was demonstrated for Hyla ebraccata by WeLLS \& SCHWARTZ (1984); and for Hyla minuta by CARDOSO \& HADDAD (1984), two 
species whose males also show fighting behavior. Two characteristics appear to be common in these aggressive calls: the lengthening of call duration and the increasing rate of emission. This report is a first approach to describe the reproduction of $C$. dubius, additional field experiments are needed to explain the main function of paternal care in this species.

ACKN()WLEDGMENTS. W.W. Benson and W.R. Heyer provided comments on early drafts: E. Ramire/ helped the field works: I. Sarima made the hlack and white pictures from slides: C.F.B. Haddad presented helpful comments. K. Facure helped in the project. FAPESP tinancially supported the study (Grant IC $89 / 2628-6$ to AAG and AP $86 / 2455-6$ to AIC) and the Smithonian Institution (Short Term Visiter Program) permitted examination of the original reconds of $C$. aluhios and C. boractiencis.

\section{REFERENCES}

CARD()S(), A.J. \& C.F.B. HADDAD. 1984. Variahilidade actistica em diferentes populaçōes e interaçoes ağressivas de Hyla mimuta (Amphibia. Anura). Ciência e Cultura 36 (8): 1393-1399.

GoSNER, K.L. 1960. A simplified table for staging anuran embryos and larvae with notes on identification. Herpetologica 16: 183-190.

Heyer, W.R. \& C.C. Mello, 1979. Description of the advertising call of Creloramphus asper and Cycloramphus duhius (Amphihia. Leptodactylidae). Pap. Avuls Depto Zool., São Paulo, 32: 193-200.

Lutz, A. 1929. Taxonomia e biologia do gênero Cycloramphus. Mem. Inst. Oswaldo Cruz 22: 5-16.

LUTz, B. 1972. Geographical and ecological notes on cisandine to platine frogs. J. Herpetol. 6:93-100.

Miranda-RibeiR(), A. DE. 1926. Notas para servirem ato estudo dos gymnobatrachios (Anura) hrasileiros. Arch. Mus. Nac. Rio Janeiro 27: 1-227.

Nussbaun, R.A. \& D.L. Schultz. 1989. Coevolution of parental care and egg size. Am. Nat. 133: 591-603.

Rose, M. \& R.E. LEMon. 1974. The vocal hehavior of spring peppers, Hyla irucifer. Copeia $1974(4): 940-950$.

Wells, K.D. 1977. The social hehavior of anuran amphibians. Anim. Behav. 25: $666-693$.

. 1981. Parental behavior of male and female frog. p. 184-197. In: R.D. Alexander \& D.W. Tinke (eds). Natural Selection and Social Behavior. New York, Chiron Press.

WELlS, K.D. \& J.J. SchWARTZ. 1984. Vocal communication in a neotropical treefrog. Hyla ehraceata: aggressive calls. Behaviour 91: 128-145.

Willians, G.C. 1975. Sex and Evolution. Princeton. Princeton Univ. Press. 